\title{
Loss of trophic complexity in saline prairie lakes as indicated by stable-isotope based community- metrics
}

\author{
Ryan N Cooper and Björn Wissel
}

\begin{abstract}
Variations in climate, watershed characteristics and lake-internal processes often result in a large variability of foodweb complexity in lake ecosystems. Some of the largest ranges in these environmental parameters can be found in lakes across the northern Great Plains as they are characterized by extreme gradients in respect to lake morphometry and water chemistry, with individual parameters often varying over several orders of magnitude. To evaluate the effects of environmental conditions on trophic complexity in prairie lake food-webs, we analyzed carbon and nitrogen stable isotopes of fishes, zooplankton and littoral macroinvertebrates in 20 lakes across southern Saskatchewan. Our two-year study identified very diverse patterns of trophic complexity, with was predominantly associated with among-lake differences. Small but significant temporal effects were also detected, which were predominantly associated with changes in productivity. The most influential parameters related to changes in trophic complexity among lakes were salinity, complexity of fish assemblage, and indicators of productivity (e.g. nutrients, Chl a). Generally, trophic diversity, number of trophic levels, and trophic redundancy were highest in productive freshwater lakes with diverse fish communities. Surprisingly, mesosaline lakes that were characterized by very low or no predation pressure from fishes were not colonized by invertebrate predators as it is often the case in boreal systems; instead, trophic complexity was further reduced. Together, prairie lake foodwebs appear to be highly sensitive to changes in salinity and the loss of piscivorous fishes, making freshwater and mesosaline lakes most vulnerable to the impacts of climate variability. This is particularly important as global circulation models predict future climate warming to have disproportionate negative impacts on hydrologic conditions in this area.
\end{abstract}

Keywords: Food web, Great Plains, Saline lakes, Stable isotopes, Trophic complexity

\section{Background}

Lakes of the northern Great Plains are strongly influenced by a high variability in climate and hydrology and, as a result, are very diverse in water chemistry and lake morphometry [1,2]. Glacial retreat has left the local terrain flat and without relief [3]. Yet, 1000s of kettle lakes formed as chunks of ice broke off glaciers, forming small depressions scattered across the landscape [4]. The semi-arid to sub-humid climate in combination with the low relief resulted in the formation of closed (endorheic) drainage basins [4]. As the continuous flushing with dilute waters that is typical for boreal lakes is

\footnotetext{
* Correspondence: bjoern.wissel@uregina.ca

* Correspondence: bjoern.wissel@uregina.ca
Department of Biology, University of Regina, 3737 Wascana Parkway, Regina, Saskatchewan S4S OA2, Canada
}

(c) 2012 Cooper and Wissel; licensee BioMed Central Ltd. This is an Open Access article distributed under the terms of the Creative

absent in these systems, inflows are almost exclusively associated with spring snow melt while surface water evaporation during summer is the most important loss of water [5].

Water chemistry in prairie lakes is largely a function of the flux of particulate and dissolved substances that are being delivered to the lakes during the spring snow melt, and the intensity of evaporative concentration of solutes during summer. Accordingly, lakes across the Canadian prairies show a large variability in nutrient levels, and salinity ranges from freshwater to hypersaline. Water depth includes shallow-mixed $(<3 \mathrm{~m})$ systems and deep-meromictic lakes $(>20 \mathrm{~m})$, and lake size ranges over several orders of magnitude $[1,6]$. Subsequently, the taxonomic composition of the biota in 
these lakes also changes with water chemistry [6]. Salinity has been reported to be most important in controlling species assemblages but other environmental factors, such as nutrient content, calcium and water depth can play crucial roles as well [7]. A recent analysis across 20 prairie lakes indicated that the strength of salinity effects differs among major taxonomic groups [8]. Accordingly, fishes were excluded with increasing salinity $\left(>2 \mathrm{~g} \mathrm{~L}^{-1}\right)$ while littoral macroinvertebrates were ubiquitous. In contrast, zooplankton were encountered over the whole salinity range, but showed a clear transition in taxonomic composition as salinity increased. Subsequently, complexity of the fish community was associated with large changes in predation pressure on lower trophic levels, as the directional changes in prey communities (shift in size distribution) indicated that complex fish assemblages were associated with high predation pressure on invertebrates (small species dominated). As the complexity of fish community decreased, large invertebrates colonized the open water, potentially taking over the position of the top-predators in mesosaline lakes $\left(2-12 \mathrm{~g} \mathrm{~L}^{-1}\right)$. Hypersaline lakes were probably bottom-up controlled as no secondary aquatic consumers were found in these systems [8].

While food-web processes may be inferred based on presence and absence of individual taxa, this information does not provide unambiguous evidence for trophic interactions (Vander Zanden and Rasmussen1997). Accordingly, to identify how trophic dynamics and complexity may change along gradients of water chemistry, morphometry and fish assemblage, we analyzed $\mathrm{C}$ and $\mathrm{N}$ stable isotopes of individual food-web components. Carbon stable isotopes $\left(\delta^{13} C\right)$ are generally used to trace the sources of primary production (energy) in food webs, while nitrogen stable isotopes $\left(\delta^{15} \mathrm{~N}\right)$ indicate the trophic position of individual taxa $[9,10]$. Biplots of carbon and nitrogen stable isotopes are helpful to visualize the trophic relationships among taxa in individual lakes. Yet, this approach may be difficult when comparing a large number of ecosystems over broader temporal or spatial scales. The interpretation of stable isotope data becomes complicated due to system-specific differences among baselines for carbon and nitrogen isotopes that are generally associated with watershed processes rather than trophic interactions [11-13]. To address this shortcoming, we adapted recently developed multivariate methods to identify, measure, and compare the variability in food-web dynamics across a large number of systems $[14,15]$.

Ultimately, our goals were to 1 ) identify trophic structure and diversity across prairie lakes using stable isotope-based community metrics, and 2) identify those environmental parameters that were most influential for changes in trophic structure. Our expectations were that hypersaline lakes would have the lowest complexity as they were inhabited only by primary producers and their consumers. Freshwater and mesosaline lakes should be characterized by similar degrees of complexity despite very different species assemblages, as the reduction in diversity due to loss of fishes should be compensated by newly immigrating invertebrate predators.

\section{Methods}

\section{Study area}

Twenty lakes across southern Saskatchewan, Canada were sampled for water chemistry, fishes, zooplankton, and littoral macroinvertebrates. This prairie region (49$53^{\circ} \mathrm{N}, 103-109^{\circ} \mathrm{W}$ ) is defined by a transition from a semi-arid climate in the southwest to a sub-humid climate in the northeast (Figure 1). Mean summer (May to

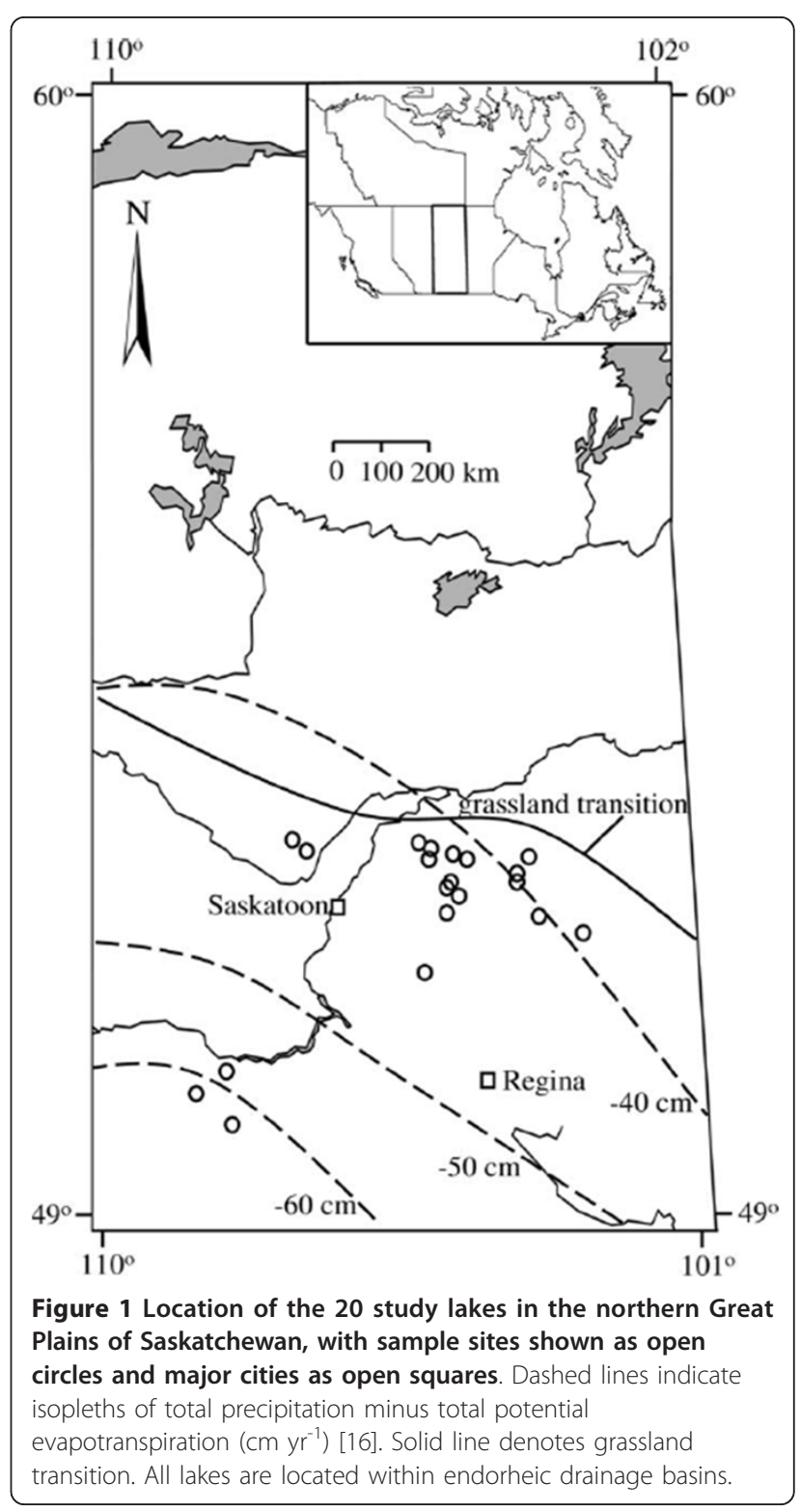


September) temperatures are $13-15^{\circ} \mathrm{C}$ and mean precipitation during this period varies from $\sim 118 \mathrm{~mm}$ in the southwest to $\sim 240 \mathrm{~mm}$ in the northeast [16]. Evapotranspiration in this area is high and may exceed precipitation by 40-60 $\mathrm{cm} \mathrm{yr}^{-1}$ [16]. All study lakes were located in endorheic drainage basins with snow melt and surface run-off as main inflows and no visible (or minor seasonal) surface outflows. Maximum depths ranged from approximately 3 to $30 \mathrm{~m}$ and average salinity measured as total dissolved solids (TDS) ranged from fresh $(<1 \mathrm{~g}$ $\mathrm{L}^{-1}$ ) to hypersaline $\left(>50 \mathrm{~g} \mathrm{~L}^{-1}\right)$. Ranges for nutrient concentrations and other water chemistry parameters were also large (Table 1). Lakes were generally polymictic, but deeper saline lakes showed meromixis with a stagnant monimolimnion.

\section{Sampling and analyses}

Lakes were sampled in June and August of 2007 and 2008, with the exception of Rabbit (not sampled in June 2008) and Middle Lakes (not sampled in August 2008), which were inaccessible due to poor road conditions. Sampling for water chemistry and zooplankton was conducted at the location of maximum depth, which was generally in the central area of each lake. Dissolved oxygen $\left(\mathrm{mg} \mathrm{L}^{-1}\right)$, total dissolved solids $\left(\mathrm{g} \mathrm{L}^{-1}\right)$, water temperature $\left({ }^{\circ} \mathrm{C}\right)$ and $\mathrm{pH}$ were measured throughout the water column in $0.5 \mathrm{~m}$ intervals in shallow lakes $(<5$ $\mathrm{m})$, or in $1 \mathrm{~m}$ intervals in deep lakes $(>5 \mathrm{~m})$ using a YSI multi probe (model 556). Water transparency was measured with a $20 \mathrm{~cm}$ black and white Secchi disk. Using a tube sampler, we collected integrated, prescreened (80- $\mu \mathrm{m}$ mesh) water samples for water chemistry (total Kjeldahl nitrogen (TKN), nitrate $\left(\mathrm{NO}_{3}{ }^{-}\right)$, total phosphorus (TP), soluble reactive phosphorus (SRP), ammonium $\left(\mathrm{NH}_{4}{ }^{+}\right)$, dissolved inorganic carbon (DIC), dissolved organic carbon (DOC), calcium (Ca) and chlorophyll $a$ concentration (Chl $a)$ ). The tube sampler was suspended in the water column either down to $6 \mathrm{~m}$ for deeper polymictic lakes, or down to $0.5 \mathrm{~m}$ above bottom sediments for shallower polymictic lakes, or down to $0.5 \mathrm{~m}$ above the monimolimnion for meromictic lakes to prevent the inclusion of water layers that are not accessible to the biota. For Chl $a$, integrated samples were filtered onto prewashed GF/C filters and stored at $-10^{\circ} \mathrm{C}$ until extracted with an acetone: methanol: water (80:15:5 by volume) solution using standard trichromatic methods [17]. For water chemistry, samples were filtered through a $0.45 \mu \mathrm{m}$ filter and the filtrate was stored at $4^{\circ}$ $\mathrm{C}$ until analysis. Quantification of $\mathrm{NO}_{3}{ }^{-}, \mathrm{NH}_{4}{ }^{+}, \mathrm{TKN}$, SRP, TDP (all $\left.\mu \mathrm{g} \mathrm{L}^{-1}\right)$, and $\mathrm{Ca}\left(\mathrm{mg} \mathrm{L}^{-1}\right)$ were performed at the University of Alberta Water Chemistry Laboratory following standard procedures $[5,18,19]$. DIC and DOC (both $\mathrm{mg} \mathrm{L}^{-1}$ ) were analyzed on a Shimadzu TOC
Analyzer 5000A at the Environmental Quality Analysis Laboratory (EQAL) at the University of Regina.

In all lakes that potentially supported fish (TDS $<20 \mathrm{~g}$ $\left.\mathrm{L}^{-1}\right)$, the near-shore fish community was sampled using a beach seine $(2 \mathrm{~m} \times 30 \mathrm{~m}, 10-\mathrm{mm}$ mesh). Twice per lake, the beach seine was pulled out perpendicular to the shore, slowly brought back describing a semi-circle, and carefully retrieved to prevent escapement of fish. Fish were euthanized with buffered tricaine methonesulphonate (MS-222; [20,21]) and kept on ice until return to the laboratory, where they were frozen. Fish species were identified according to Scott and Crossman [22] and assemblages were characterized by complexity (high complexity - assemblages include piscivores, planktivores and benthivores; low complexity - assemblages lacked piscivores, and fishless), with complexity largely representing the number of trophic levels within the fish community.

Small and large zooplankton taxa were sampled using $80-\mu \mathrm{m}$ (30 cm diameter) and 500- $\mu \mathrm{m}$ (50 cm diameter) conical plankton nets, respectively, which were towed vertically from maximum depth to the surface. For stable isotope analyses, samples were collected without preservation, kept on ice until the return to the laboratory where they were frozen. For species abundance and taxonomic analyses a second set of samples from each net was preserved with an ethanol-sucrose solution. Individuals were identified to species for anostraca, cladocerans, and copepods [23-25]. Rotifers were identified to genus but were not analyzed for stable isotopes due to their small size.

Littoral macroinvertebrates were collected from nearshore areas in depths up to $1 \mathrm{~m}$ using a large sweep net $(500 \mu \mathrm{m})$. Samples were pooled from different littoral habitats (gravel, sand, mud, and macrophyte stands, if available) that were each sampled for approximately 10 min. Samples were preserved in ethanol to estimate presence/absence, and specimens were identified to order [24]. For stable isotope analyses, a second set of samples was collected without preservation and the samples were kept on ice until the return to the laboratory where they were frozen.

\section{Stable isotope analyses}

Fish were thawed and a small piece $(\sim 1 \mathrm{~g})$ of lateral muscle tissue [26] was extracted for stable isotope analysis [27]. The muscle tissue was rinsed with deionized water, dried at $50^{\circ} \mathrm{C}$, ground to a homogeneous powder, and packed into a tin capsule. For each species per lake, 5 to 10 individuals were analyzed for stable isotopes. Zooplankton and littoral macroinvertebrates were rinsed with deionized water and abundant taxa from each group of invertebrates (cladocerans, calanoids, 
Table 1 Chemical and physical characteristics of the 20 study lakes

\begin{tabular}{|c|c|c|c|c|c|c|c|c|c|c|c|c|c|c|c|c|c|c|}
\hline Site & $\begin{array}{l}\text { Latitude }^{\circ} \\
\mathrm{N}(\mathrm{dd})\end{array}$ & $\begin{array}{l}\text { Longlitude }{ }^{\circ} \\
\text { W(dd) }\end{array}$ & $\begin{array}{l}\text { Elevation } \\
\text { (masl) }\end{array}$ & $\begin{array}{c}\text { Surface } \\
\text { Area } \\
\left(\mathbf{k m}^{2}\right)\end{array}$ & $\begin{array}{l}\text { Depth } \\
(\mathrm{m})\end{array}$ & $\begin{array}{l}\text { TDS } \\
\left(\mathrm{g} \mathrm{L}^{-1}\right)\end{array}$ & $\begin{array}{l}\text { Secchi } \\
\text { (m) }\end{array}$ & $\begin{array}{c}\mathrm{Chl} \mathrm{a} \\
\left(\mu \mathrm{g} \mathrm{L} \mathrm{L}^{1}\right)\end{array}$ & $\mathrm{pH}$ & $\begin{array}{c}\text { TKN } \\
\left(\mu \mathrm{g} \mathrm{L}^{1}\right)\end{array}$ & $\begin{array}{c}\mathrm{NO}_{3} \\
\left(\mu \mathrm{g} \mathrm{L}^{-1}\right)\end{array}$ & $\begin{array}{c}\mathrm{NH}_{4}^{+} \\
\left(\mu \mathrm{g} \mathrm{L}^{-1}\right)\end{array}$ & $\begin{array}{c}\mathrm{TP} \\
\left(\mu \mathrm{g} \mathrm{L^{1 }}\right)\end{array}$ & $\begin{array}{c}\text { SRP } \\
\left(\mu \mathrm{g} \mathrm{L}^{-1}\right)\end{array}$ & $\begin{array}{c}\mathrm{Ca} \\
\left(\mathrm{mg} \mathrm{L}^{-1}\right)\end{array}$ & $\begin{array}{c}\text { DIC } \\
\left(\mathrm{mg} \mathrm{L}^{-1}\right)\end{array}$ & $\begin{array}{c}\mathrm{DOC} \\
\left(\mathrm{mg} \mathrm{L}^{-1}\right)\end{array}$ & $\begin{array}{l}\text { Mixis } \\
\text { Type }\end{array}$ \\
\hline Edouard & 52.38 & 104.33 & 580 & 1.0 & 5 & 0.4 & 2 & 25 & 8.3 & 1488 & 278 & 299 & 136 & 91 & 49 & 42 & 21 & Polymictic \\
\hline Pelletier & 49.98 & 107.93 & 825 & 1.0 & 8 & 0.5 & 2 & 17 & 8.6 & 746 & 4 & 44 & 12 & 8 & 23 & 74 & 15 & Polymictic \\
\hline Kipabisku & 52.56 & 104.20 & 522 & 5.2 & 7 & 0.6 & 2 & 7 & 8.3 & 1159 & 287 & 31 & 173 & 130 & 83 & 50 & 26 & Polymictic \\
\hline Lenore & 52.50 & 104.98 & 537 & 10.0 & 9 & 1.1 & 2 & 15 & 8.5 & 809 & 10 & 45 & 9 & 2 & 59 & 59 & 26 & Polymictic \\
\hline Humboldt & 52.15 & 105.10 & 544 & 19.1 & 6 & 1.1 & 1 & 25 & 8.5 & 1469 & 243 & 85 & 310 & 206 & 94 & 49 & 23 & Polymictic \\
\hline Clair & 51.98 & 104.05 & 524 & 1.2 & 3 & 1 & 1 & 22 & 8.7 & 1317 & 221 & 32 & 33 & 10 & 73 & 49 & 25 & Polymictic \\
\hline Wakaw & 52.66 & 105.58 & 511 & 10.7 & 7 & 2 & 2 & 12 & 8.1 & 1066 & 17 & 134 & 9 & 5 & 164 & 39 & 21 & Polymictic \\
\hline Shannon & 52.63 & 105.43 & 549 & 1.0 & 7 & 2 & 2 & 12 & 8.8 & 1420 & 224 & 59 & 40 & 15 & 65 & 65 & 24 & Polymictic \\
\hline Fishing & 51.83 & 103.50 & 529 & 32.1 & 12 & 2 & 3 & 14 & 8.4 & 1104 & 2 & 37 & 9 & 7 & 99 & 57 & 23 & Polymictic \\
\hline Rabbit & 52.60 & 107.00 & 504 & 4.6 & 4 & 6 & 1 & 10 & 8.7 & 1734 & 154 & 30 & 210 & 153 & 76 & 99 & 36 & Polymictic \\
\hline Charron & 52.40 & 104.33 & 556 & 4.0 & 7 & 6 & 2 & 25 & 8.8 & 2158 & 153 & 75 & 145 & 79 & 67 & 90 & 33 & Polymictic \\
\hline Arthur & 52.60 & 107.00 & 504 & 4.6 & 4 & 6 & 1 & 10 & 8.7 & 1734 & 154 & 30 & 210 & 153 & 76 & 99 & 36 & Polymictic \\
\hline Middle & 52.56 & 105.16 & 534 & 5.9 & 5 & 11 & 4 & 21 & 8.7 & 3191 & 240 & 77 & 95 & 6 & 103 & 95 & 55 & Meromictic \\
\hline Deadmoose & 52.31 & 105.16 & 539 & 10.9 & 29 & 11 & 3 & 11 & 8.7 & 1788 & 13 & 113 & 43 & 9 & 95 & 65 & 30 & Meromictic \\
\hline Waldsea & 52.28 & 105.20 & 533 & 4.7 & 11 & 12 & 3 & 10 & 8.6 & 1608 & 6 & 67 & 23 & 12 & 226 & 55 & 42 & Meromictic \\
\hline Redberry & 52.71 & 107.15 & 502 & 60.7 & 11 & 13 & 3 & 4 & 8.7 & 2011 & 10 & 32 & 27 & 19 & 61 & 131 & 43 & Polymictic \\
\hline Antelope & 50.28 & 108.40 & 701 & 13.8 & 4 & 15 & 1 & 14 & 8.9 & 4816 & 117 & 281 & 126 & 63 & 37 & 189 & 72 & Polymictic \\
\hline Success & 50.48 & 108.01 & 715 & 0.7 & 14 & 20 & 4 & 9 & 8.9 & 12657 & 22 & 7585 & 134 & 115 & 14 & 350 & 49 & Meromictic \\
\hline L. Manitou & 51.75 & 105.50 & 493 & 12.8 & 5 & 44 & 2 & 16 & 8.5 & 5741 & 11 & 133 & 321 & 47 & 50 & 91 & 112 & Polymictic \\
\hline Snakehole & 50.30 & 108.28 & 858 & 1.3 & 2 & 64 & 2 & 7 & 8.5 & 14356 & 43 & 187 & 636 & 126 & 53 & 109 & 318 & Polymictic \\
\hline
\end{tabular}

Values, except elevation and surface area, are averaged over the four sampling periods (June 2007, August 2007, June 2008, and August 2008; Rabbit Lake was not sampled in June 2008 and Middle Lake was not sampled August 2008). Lakes are sorted by increasing salinity (TDS). 
cyclopoids, pelagic macroinvertebrates, littoral macroinvertebrates) were selected that had sufficient sample material for stable isotope analysis. Depending on the taxon, between 1 (most littoral macroinvertebrates) and 150 individuals (small cladocerans and copepods) were packed into tin capsules and dried at $50^{\circ} \mathrm{C}$.

All tin capsules were combusted in an Elemental Combustion System (Costech) that was connected to a ThermoQuest (Finnigan-MAT) Delta Plus isotope ratio mass spectrometer (IRMS). Bovine liver and wheat flour were used as internal laboratory standards. Carbon and nitrogen isotopes are reported in the conventional $\delta$ notation in \%o, relative to Vienna Pee Dee Belemnite and atmospheric $\mathrm{N}_{2}$ for carbon and nitrogen stable isotopes, respectively [9]. Samples that were split in the laboratory and analyzed as duplicates $(n=121)$ gave isotopic compositions that agreed within a $0.2 \%$ range for both $\delta^{13} \mathrm{C}$ and $\delta^{15} \mathrm{~N}$.

\section{Statistical analyses}

Stable isotope studies often rely on $\delta^{13} \mathrm{C}$ and $\delta^{15} \mathrm{~N}$ biplots to identify the importance of different energy sources $\left(\delta^{13} \mathrm{C}\right)$ and trophic positions $\left(\delta^{15} \mathrm{~N}\right)$. Due to the complexity of this study (20 lakes, 2 years, 2 seasons), an additional, more synoptic approach was required to identify and quantify the changes in food-web complexity along environmental gradients.

First, to quantify the within-lake variability in stable isotope values for individual taxa, we analyzed the range of $\delta^{13} \mathrm{C}$ and $\delta^{15} \mathrm{~N}$ values for common taxonomic groups within lakes over the 2-year period. We conducted this analysis on cladocerans, copepods and amphipods as these taxa were available for most sampling dates in almost all lakes. Calanoid and cyclopoid copepods were pooled for this analysis because no significant differences in temporal variability were detected between these two groups when they co-occurred in lakes $(p>$ $0.05)$. As the range in stable isotope values differed among lakes, we conducted multiple linear regressions to identify those environmental parameters that were most influential in explaining the observed patterns. Ranges over the two-year span in $\delta^{13} \mathrm{C}$ and $\delta^{15} \mathrm{~N}$ of cladocerans and copepods were independent variables, and averaged (over the four sampling events), $\log _{10}$-transformed values of environmental parameters were dependent variables.

Subsequently, to identify if the temporal variability in stable isotope values was random or followed systematic temporal shifts between seasons or years, we used Euclidian geometry and circular statistics [15]. The analysis was conducted for two different types of time intervals: 1) June 2007 to August 2007, and June 2008 to August 2008 to represent seasonal changes, and 2) June 2007 to June 2008, and August 2007 to August 2008 for annual differences. We included cladocerans, copepods, and amphipods into the analyses as these taxa were ubiquitous and occurred at all sampling times (see above). For each taxon, temporal changes in isotopic values between two $\delta^{13} \mathrm{C}-\delta^{15} \mathrm{~N}$ bi-plots (representing two time periods) were expressed as angle of change $(\theta)$ and magnitude of change (vector), which together characterized the directional isotopic change between the two time periods. Subsequently, from all the taxa within each lake, a mean angle of change $(\mu)$ was calculated, and Rayleigh's test was used to determine if $\mu$ was significant. A significant change with an angle around $90^{\circ}$ or $270^{\circ}$ indicated an increase or decrease in $\delta^{13} \mathrm{C}$, respectively, while a respective angle around $360^{\circ}$ or $180^{\circ}$ represented an increase or decrease in $\delta^{15} \mathrm{~N}$. All circular statistics were calculated using Oriana 3.0.

Finally, to characterize changes in trophic structure among lakes we calculated lake-specific stable-isotope based community metrics [28]. There are six community-wide measures to determine the characteristics of food-web structure. The first four reflect trophic diversity within $\delta^{13} \mathrm{C}-\delta^{15} \mathrm{~N}$ bi-plots, while the other two represent trophic redundancy, or how closely positioned taxa are to each other within their respective niches. 1) Range in $\delta^{13} \mathrm{C}(\mathrm{CR})$, measured as difference between maximum and minimum $\delta^{13} \mathrm{C}$ values. A large $\mathrm{CR}$ implies a significant difference in basal resources, which demonstrates distinct niches (e.g., littoral vs. pelagic). 2) Range in $\delta^{15} \mathrm{~N}$ (NR), measured as the difference between maximum and minimum $\delta^{15} \mathrm{~N}$ values. This metric demonstrates the difference between the highest and lowest trophic levels, and a large NR implies more trophic levels. 3) Total area (TA), measures as convex hull area [29] enclosing all taxa within the bi-plot space. This metric represents the entire niche space or total trophic diversity. 4) Mean distance to centroid (CD), measured as average Euclidean distance of each taxa to the centroid (mean $\delta^{13} \mathrm{C}-\delta^{15} \mathrm{~N}$ value for all taxa in the bi-plot). This metric represents the average trophic diversity within the food web, and is not as susceptible to outliers as TA. 5) Nearest neighbor distance (NND), measured as average Euclidean distance of each taxon to its nearest neighbor within the bi-plot area. This is a measure of overall species packing, or trophic redundancy. 6) Standard deviation of nearest neighbor distance (SDNND), measuring evenness of species packing. Low values demonstrate an even distribution of taxa within the food web.

Once all metrics were calculated for the 20 study lakes (averaged over the 2-year sampling period), multiple linear regressions were used to identify environmental parameters ( $\log _{10}$-transformed) that significantly contributed to the variability of these six metrics (SPSS, version 16.0). Furthermore, we conducted an Analysis of 
Variance (ANOVA, using SPSS, version 16.0) to test if the differences in the metrics followed the three salinity ranges where changes in biodiversity occurred: freshwater (<2 $\left.\mathrm{g} \mathrm{L}^{-1}, \mathrm{n}=9\right)$; mesosaline (2-12 $\left.\mathrm{g} \mathrm{L}^{-1}, \mathrm{n}=7\right)$; and saline $\left(>12 \mathrm{~g} \mathrm{~L}^{-1}, \mathrm{n}=4\right)[8]$.

\section{Results}

\section{Biota}

Among the 21 species of zooplankton Daphnia pulex, D. similis, D. rosea, D. galeata mendotae, Diaphanosoma birgei, and Ceriodaphnia lacustris were the most abundant cladocerans. Leptodiaptomus sicilis and Diaptomus nevadensis were abundant calanoid copepods, and Diacyclops thomasi was the most common cyclopoid species. The brachiopod Artemia franciscana dominated in hypersaline lakes. Littoral sampling resulted in 18 classes of macroinvertebrates, with amphipods (Hyalella azteca and Gammarus lacustris) and zygopterans being most abundant. Yellow perch (Perca flavescens), nine-spine stickleback (Pungitius pungitius), Brook stickleback (Culaea inconstans), fathead minnow (Pimephales promelas), northern pike (Esox lucius), and walleye (Sander vitreus) were the most common fish species.

\section{Stable isotope patterns}

The 20 study lakes showed a broad range of lake-specific variation in stable isotope values of individual taxa over the two-year study period. Linear regressions demonstrated that the variability in $\delta^{13} \mathrm{C}$ was mostly dependent on nutrient levels and productivity measures (Table 2). For cladocerans, the most important parameters were TP, SRP, and Chl $a$, and variability in $\delta^{13} \mathrm{C}$ for copepods was related to Chl $a$, SRP, Secchi depth, and TP. Amphipod variability in $\delta^{13} \mathrm{C}$ had no significant correlation to any parameters. For $\delta^{15} \mathrm{~N}$, cladoceran values had a significant positive relationship to surface area, while Secchi depth had a significant negative effect.

Table 2 Pearson correlation coefficients $(r)$ between environmental parameters and temporal variation (range) of $\delta^{13} \mathrm{C}(\mathrm{C})$ and $\delta^{15} \mathrm{~N}(\mathrm{~N})$ for cladocerans (clad), copepods (cope) and amphipods (amph) over the two year period

\begin{tabular}{lcccccc}
\hline & clad C & clad N & cope C & cope N & amph C & amph N \\
\cline { 2 - 7 } Variables & -0.33 & -0.14 & 0.01 & -0.09 & 0.18 & 0.03 \\
\hline Salinity & $\mathbf{0 . 4 6}$ & 0.19 & $\mathbf{0 . 4 3}$ & -0.01 & 0.01 & $\mathbf{0 . 5 4}$ \\
SRP & $\mathbf{0 . 5 5}$ & 0.15 & $\mathbf{0 . 3 7}$ & 0.04 & 0.05 & $\mathbf{0 . 4 6}$ \\
TP & -0.01 & 0.39 & 0.19 & 0.01 & 0.00 & -0.03 \\
Surface Area & $\mathbf{0 . 4 2}$ & 0.20 & $\mathbf{0 . 5 9}$ & $\mathbf{0 . 3 2}$ & 0.09 & $\mathbf{0 . 4 9}$ \\
Chl a & -0.32 & $\mathbf{- 0 . 5 5}$ & $\mathbf{- 0 . 4 0}$ & -0.22 & -0.09 & -0.39 \\
Secchi & 0.13 & 0.23 & 0.04 & 0.24 & -0.17 & -0.23 \\
Fish complexity & &
\end{tabular}

Bold denotes significance $(p<0.05)$
The $\delta^{15} \mathrm{~N}$ values of copepods showed a positive correlation to Chl $a$. Amphipod variability in $\delta^{15} \mathrm{~N}$ values had significant relationships with SRP, Chl a, and TP. Stepwise multiple linear regressions determined that TP and fish complexity had significant positive influences on Cladoceran $\delta^{13} \mathrm{C}$, while Chl $a$ had a positive correlation to Copepod $\delta^{13} \mathrm{C}$ (Table 3). For Cladoceran $\delta^{15} \mathrm{~N}$, Secchi depth showed a significant negative correlation and lake surface area had a significant positive relationship, while SRP had a significant positive correlation to amphipod $\delta^{15} \mathrm{~N}$ (Table 3). Copepod $\delta^{13} \mathrm{C}$ and Amphipod $\delta^{15} \mathrm{~N}$ were not significant correlation to any environmental parameters.

Circular statistics revealed minor, yet systematic temporal changes in $\delta^{13} \mathrm{C}$ and $\delta^{15} \mathrm{~N}$. Intra-annual variation (June to August) showed a small significant shift to higher $\delta^{13} \mathrm{C}$ values for zooplankton and macroinvertebrates, indicated by mean vectors of change $(\mu)$ of $61.0^{\circ}$ in 2007 (Rayleigh's test, $p<0.01, \mathrm{n}=36$; Figure 2a) and $101.2^{\circ}$ in 2008 (Rayleigh's test $p<0.01, \mathrm{n}=33$; Figure $2 \mathrm{~b})$. As the angle of change was largely associated with the $\mathrm{X}$-axis $\left(\delta^{13} \mathrm{C}\right)$, no systematic intra-annual changes were obvious for $\delta^{15} \mathrm{~N}$ (Y-axis). Yet in both years, several lakes had lower $\delta^{15} \mathrm{~N}$ during August, shown by individual angles of change $(\theta)$ associated with negative values along the $\mathrm{Y}$-axis (Figure $2 \mathrm{a}$ and $2 \mathrm{~b}$ ). Inter-annual variation was identified only for the June sampling, which showed a small significant increase in $\delta^{15} \mathrm{~N}$ from 2007 to 2008 , with a mean vector of change $(\mu)$ of $345.0^{\circ}$ (Rayleigh's test $p<0.01, \mathrm{n}=33$; Figure 3).

Food-web dynamics - Based on stable isotope data, freshwater lakes had the most complex food webs, containing the greatest number of trophic levels as well as the most taxa (Figures 3 and 4). Cladocerans (Daphnia sp., Ceriodaphnia sp., Bosmina sp., and Diaphanosoma $s p$.) occupied the trophic position of the primary consumer within the pelagic habitat (low $\delta^{13} \mathrm{C}$ ), and invertebrate predators such as Chaoborus and Leptodora were secondary pelagic consumers. Fathead minnows, as well as small $(<10 \mathrm{~cm})$ walleye and yellow perch were predominantly zooplanktivorous as evidenced by intermediate $\delta^{15} \mathrm{~N}$ and low $\delta^{13} \mathrm{C}$ values. In the littoral habitat

Table 3 Stepwise multiple linear regression results for temporal variation (range) in $\delta^{13} \mathrm{C}$ and $\delta^{15} \mathrm{~N}$ of cladocerans, copepods and amphipods as a function of environmental parameters

\begin{tabular}{llcc}
\hline Metric & Standardized coefficients & $\boldsymbol{p}$ & $\boldsymbol{r}_{\text {adj. }}$ \\
\hline Cladoceran $\delta^{13} \mathrm{C}$ & $0.6 \mathrm{TDP}+0.1$ fish complexity & $<0.01$ & 0.50 \\
Cladoceran $\delta^{15} \mathrm{~N}$ & $-0.6 \mathrm{Secchi}+0.4$ surface area & $<0.01$ & 0.47 \\
Copepod $\delta^{13} \mathrm{C}$ & $0.6 \mathrm{Chl} a$ & $<0.01$ & 0.31 \\
Amphipod $\delta^{15} \mathrm{~N}$ & $0.5 \mathrm{SRP}$ & $<0.01$ & 0.24 \\
\hline
\end{tabular}

No significant regressions ( $p>0.05$ ) were found for copepod $\delta^{15} \mathrm{~N}$ and amphipod $\delta^{13} \mathrm{C}$ 


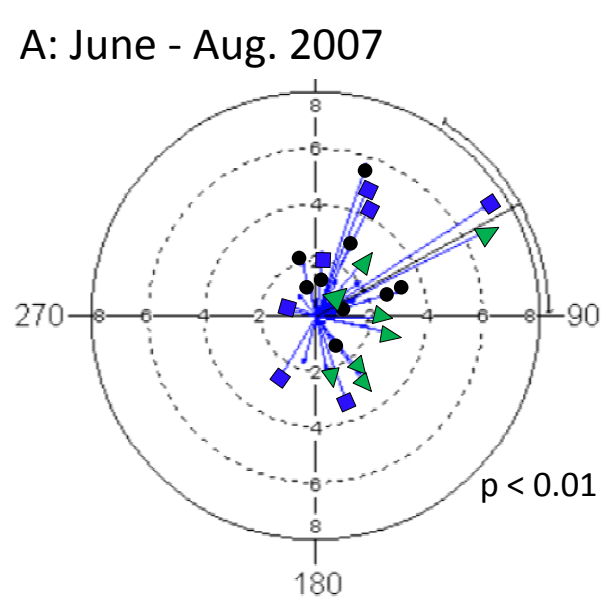

\section{C: June 2007 - June 2008}

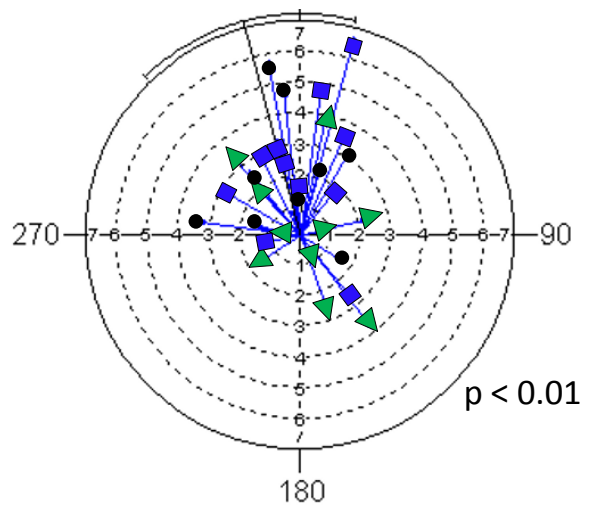

\section{B: June - Aug. 2008}

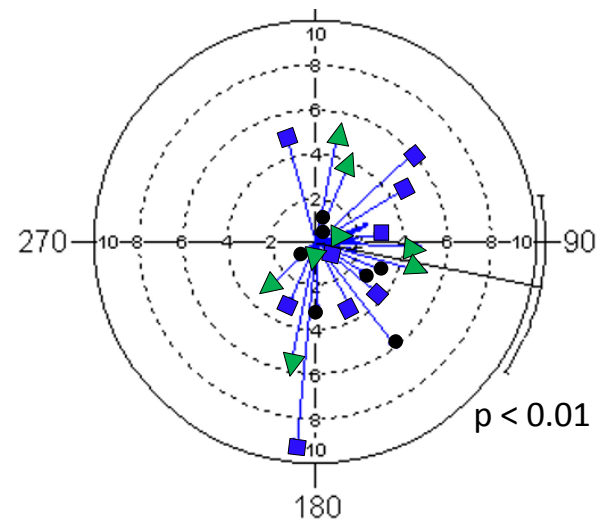

cladocerans

$\triangle$ copepods

amphipods

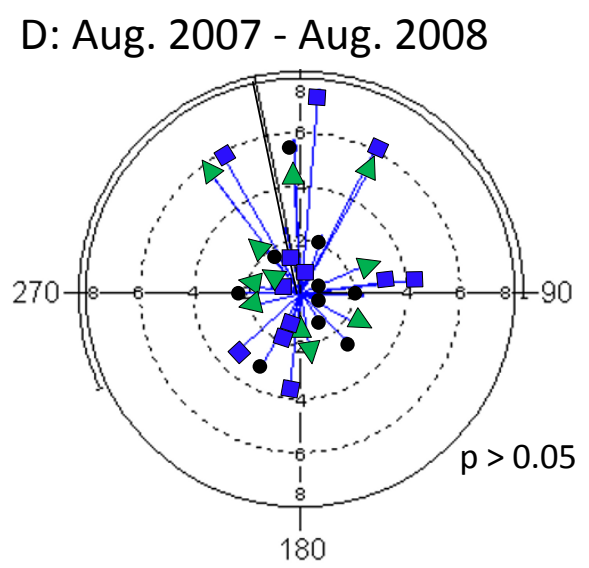

Figure 2 Results of circular statistics to quantify direction and magnitude of temporal variation (Schmidt et al., 2007) of $\delta^{13} \mathrm{C}$ and $\delta^{15} \mathrm{~N}$ values in the $\mathbf{2 0}$ study lakes for selected bioata. Periods of temporal change were either seasonal: (A) June to August 2007, (B) June to August 2008, or annual: (C) June 2007 to June 2008 (D) August 2007 to August 2008. The arrow diagrams represent the directional changes in $\delta^{13} \mathrm{C}$ and $\delta^{15} \mathrm{~N}$ values between time intervals for cladocerans (blue square), copepods (green triangle), and littoral macroinvertebrates (black circle) in each individual lake. Blue arrows represent the angle of change $(\theta)$ and the length of the arrow represents the magnitude of change (vector). The mean vector of change (across all lakes and taxonomic groups, $\mu$ ) is represented by the black line from the origin to the outside of the diagram. The curved line at the end of the mean vector line on the outside of the graph is the $95 \%$ confidence interval of the mean vector of change, and p-values indicate if the direction of change was significant for a particular time period. For time period (A) a significant shift was observed, which was associated with increases in both $\delta^{13} \mathrm{C}$ and $\delta^{15} \mathrm{~N}$. For time periods (B) and (C), significant shift were associated with either $\delta^{13} \mathrm{C}$ or $\delta^{15} \mathrm{~N}$, respectively, and for time period (D) no significant changes were recorded.

(high $\delta^{13} \mathrm{C}$ ), amphipods were the most common primary consumer, with predatory insect larvae (e.g. Zygoptera) as secondary consumers. Intermediate sized perch (10$15 \mathrm{~cm}$ ), shiners, and Brook and nine-spine stickleback foraged more in the littoral zone and, at times, acted as tertiary consumers in the littoral. Larger piscivorous fish (walleye, pike, and perch $>15 \mathrm{~cm}$ ) were top-predators in freshwater lakes and often incorporated both pelagic and littoral prey into their diet, as shown by intermediate $\delta^{13} \mathrm{C}$ and high $\delta^{15} \mathrm{~N}$ values.

In contrast, saline lakes had simplified food webs and strongly reduced taxonomic richness (Figure 4). Fishes were absent in mesosaline and saline lakes, except Redberry Lake. Instead, the highest trophic levels in the pelagic and littoral areas were occupied by the predatory copepod D. nevadensis and zygopterans, respectively, even in Redberry Lake, where sticklebacks had slightly lower $\delta^{15} \mathrm{~N}$ values than $D$. nevadensis. In hypersaline Snakehole Lake, primary consumers represented the highest trophic level in both pelagic and littoral habitats, as only halophilic $A$. franciscana and larvae of the brine fly Ephydra sp. were encountered. In the second hypersaline lake, Little Manitou, taxa that are usually associated with the littoral zone (e.g. harpacticoids) were 

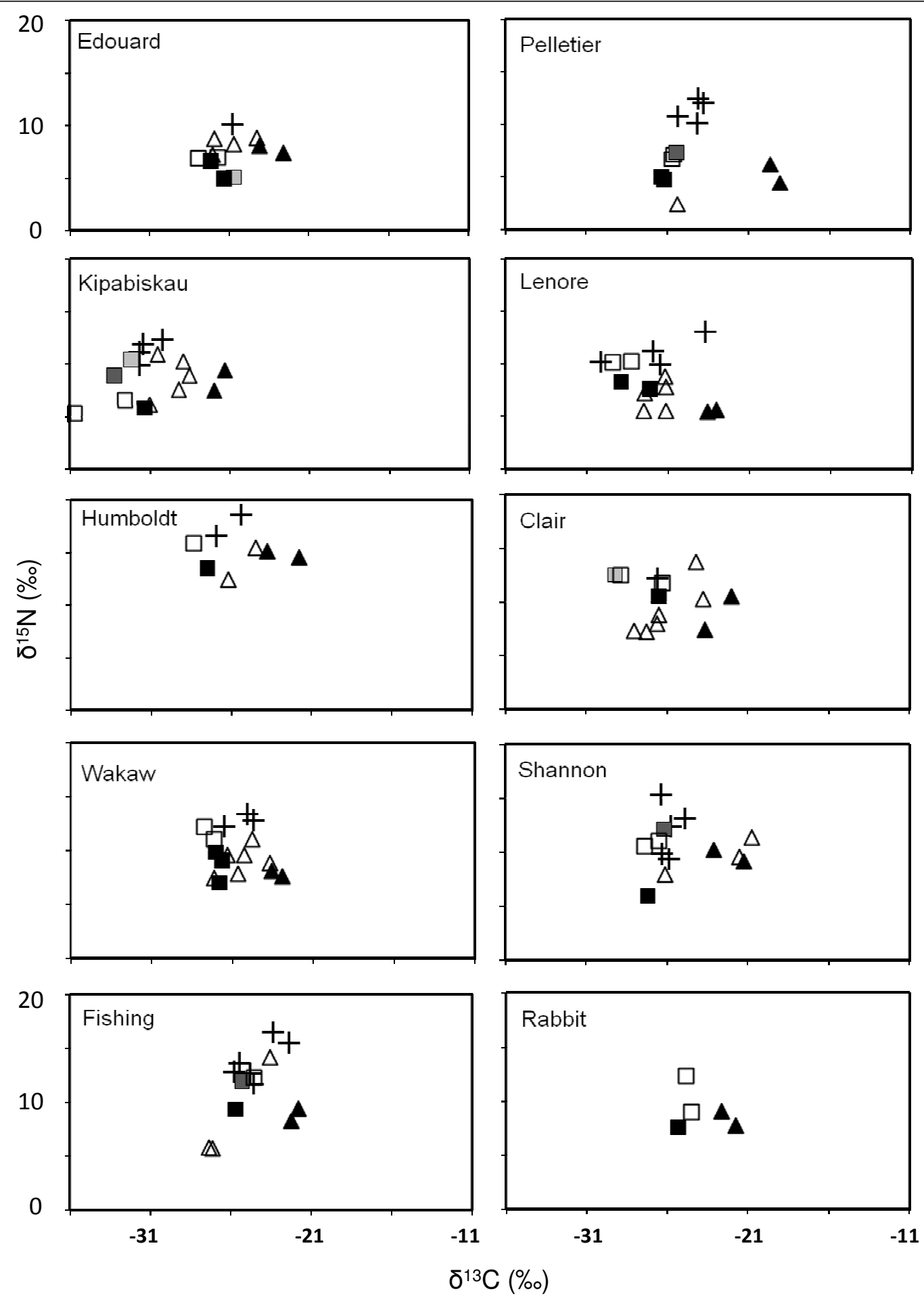

Figure $3 \mathrm{~A}$ and B: Stable isotope bi-plots for the 20 study lakes, with $\delta^{15} \mathrm{~N}$ on the $\mathrm{Y}$-axis and $\boldsymbol{\delta}^{13} \mathrm{C}$ on the X-axis. Lakes are sorted by salinity (see Table 1), increasing within rows from row 1 to row 10. Data are averaged over the four sampling dates (June 2007, August 2007,

June 2008, August 2008). Fish taxa are indicated by crosses (+), zooplankton by squares ( $\square$ ), and littoral invertebrate by triangles $(\Delta)$. Zooplankton is further separated into cladocerans (black squares, - ), copepods (open squares, 口), invertebrate predators (i.e., Leptodora or Chaoborus; dark grey squares, $\mathbf{-}$ ) and other macroinvertebrates (e.g., corixids; light grey squares, $\mathbf{- 1}$ ). Within littoral invertebrates, amphipods are indicated by black triangles $(\mathbf{\Delta})$. 

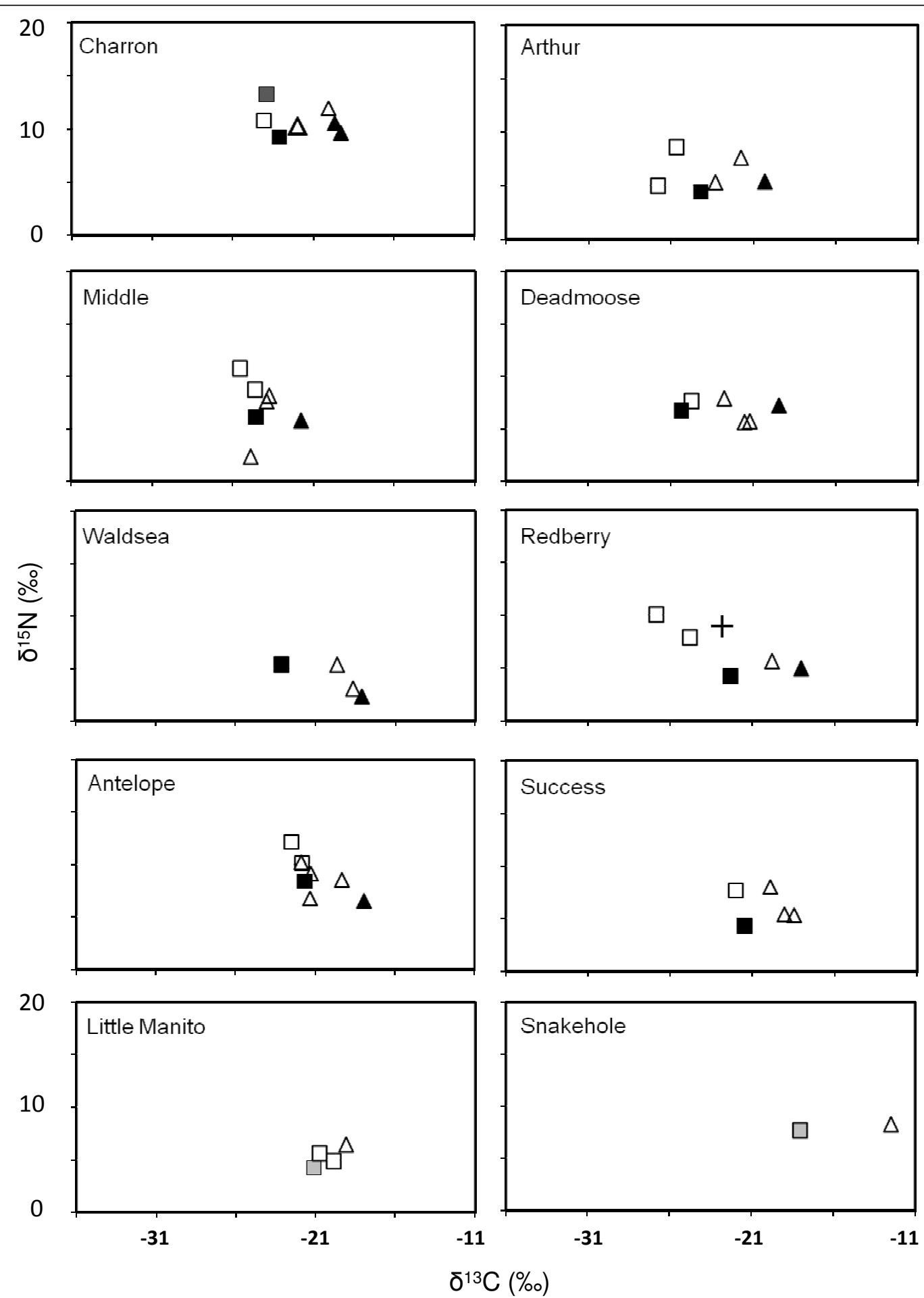

Figure $4 \mathrm{~A}$ and B: Stable isotope bi-plots for the 20 study lakes, with $\delta^{15} \mathrm{~N}$ on the $\mathrm{Y}$-axis and $\delta^{13} \mathrm{C}$ on the X-axis. Lakes are sorted by salinity (see Table 1), increasing within rows from row 1 to row 10. Data are averaged over the four sampling dates (June 2007, August 2007,

June 2008, August 2008). Fish taxa are indicated by crosses (+), zooplankton by squares ( $\square$ ), and littoral invertebrate by triangles $(\Delta)$. Zooplankton is further separated into cladocerans (black squares, $\mathbf{- 1}$ ), copepods (open squares, $\square$ ), invertebrate predators (i.e., Leptodora or Chaoborus; dark grey squares, - ) and other macroinvertebrates (e.g., corixids; light grey squares, $\mathbf{-})$. Within littoral invertebrates, amphipods are indicated by black triangles $(\mathbf{\Delta})$. 
isotopically indistinguishable from pelagic species such as A. franciscana and L. sicilis.

Littoral invertebrate predators (e.g. Zygoptera, Dysticidae, and corixids) did not actively invade the pelagic zone after the exclusion of fishes to take over the position of the top predator. Even though these taxa were frequently encountered in pelagic samples, based on their stable isotope values they continuously relied on littoral prey, indicating passive dispersal rather that an active migration into the open water.

Finally, in three lakes (Kipabiskau, Humboldt and Redberry), we consistently encountered copepods that had low $\delta^{13} \mathrm{C}$ values relative to all other pelagic crustaceans. These $\delta^{13} \mathrm{C}$ values were also more negative than $\delta^{13} \mathrm{C}$ of primary producers that were analyzed as particulate organic carbon (POC, data not shown).

\section{Stable isotope metrics}

The differences in food-web structures among prairie lakes derived from bi-plots were confirmed by community-wide metrics. Freshwater lakes had a large $\delta^{13} \mathrm{C}$ range (CR; 4.9 - 9.4, mean: 6.9), compared to mesosaline (CR; 3.6 - 8.8, mean: 5.5), and saline lakes (CR: 2.0 - 5.6, mean: 3.9) (Table 4). Freshwater lakes also had the highest $\delta^{15} \mathrm{~N}$ ranges (NR: $5.2-10.8$, mean: 7.7; Table 4). Redberry Lake had the highest NR for mesosaline lakes (5.8), while Snakehole Lake had the lowest NR among all lakes (0.7). Total area (TA) showed the greatest differences between fresh and saline systems. Freshwater lakes had a TA range of 13.7 to 49.2 (mean: 34.6; Table 4). In contrast, mesosaline lakes ranged from 6.8 to 25.5 (mean: 13.6) and saline lakes ranged from 2.8 to 14.1 (mean 7.6). The mean centroid distances (CD, indicating trophic diversity) in freshwater lakes (1.9 - 3.6, mean: $2.8)$ were slightly larger than in mesosaline lakes (1.7 3.4, mean: 2.3 ) and saline lakes $(1.1 ; 2.0$, mean: 1.7$)$, while saline lakes had greater mean nearest neighbor distances (NND, trophic redundancy). The standard deviations of NND (SDNND; Table 4) were not significantly different among the lakes.

Freshwater lakes are listed first, followed by mesosaline and saline lakes. A large CR $\left(\max \delta^{13} \mathrm{C}-\min \delta^{13} \mathrm{C}\right)$ implies a significant difference in basal resources (littoral-pelagic). A large NR $\left(\max \delta^{15} \mathrm{~N}-\min \delta^{15} \mathrm{~N}\right)$ demonstrates the trophic level variation. Total area (TA) encloses all species within the bi-plot space, representing total trophic diversity within the lake. Centroid distance (CD) is the average Euclidean distance of each species to the mean $\delta^{13} \mathrm{C}-\delta^{15} \mathrm{~N}$ value for all species in the bi-plot, measuring the average trophic diversity within the food web. Mean nearest neighbor distance (NND) is the average Euclidean distance of each species to its nearest neighbor and measures overall species
Table 4 Summary of community-wide metrics based on $\delta^{13} \mathrm{C}$ and $\delta^{15} \mathrm{~N}$ analysis [14] for the 20 study lakes

\begin{tabular}{|c|c|c|c|c|c|c|}
\hline $\begin{array}{l}\text { Lake } \\
\text { Name }\end{array}$ & CR & NR & Area & $C D$ & NND & SDNND \\
\hline Eduoard & 5.28 & 5.20 & 13.73 & 1.90 & 1.21 & 0.58 \\
\hline Kipabiskau & 9.44 & 7.04 & 46.49 & 2.93 & 1.37 & 0.75 \\
\hline Pelletier & 7.30 & 10.06 & 49.20 & 3.56 & 0.94 & 0.78 \\
\hline Lenore & 7.10 & 7.65 & 38.02 & 3.46 & 1.23 & 0.78 \\
\hline Humboldt & 8.46 & 6.17 & 31.34 & 2.77 & 1.67 & 0.63 \\
\hline Clair & 7.19 & 6.53 & 31.45 & 2.79 & 1.20 & 0.88 \\
\hline Wakaw & 4.86 & 6.40 & 21.74 & 2.25 & 1.01 & 0.44 \\
\hline Shannon & 6.57 & 9.40 & 37.04 & 2.88 & 1.19 & 0.72 \\
\hline Fishing & 5.57 & 10.77 & 40.23 & 2.88 & 1.11 & 0.72 \\
\hline Mean \pm SD & $\begin{array}{c}6.8 \pm \\
1.5 \\
\end{array}$ & $\begin{array}{c}7.7 \pm \\
1.9 \\
\end{array}$ & $\begin{array}{c}34 \pm \\
11 \\
\end{array}$ & $\begin{array}{c}2.8 \pm \\
0.5 \\
\end{array}$ & $\begin{array}{c}1.2 \pm \\
0.2 \\
\end{array}$ & $\begin{array}{c}0.70 \pm \\
0.1 \\
\end{array}$ \\
\hline Rabbit & 3.58 & 4.71 & 11.31 & 1.97 & 1.93 & 0.77 \\
\hline Charron & 4.74 & 4.00 & 12.70 & 2.14 & 1.54 & 0.51 \\
\hline Arthur & 6.47 & 4.10 & 17.75 & 2.48 & 2.38 & 1.00 \\
\hline Middle & 3.81 & 5.00 & 9.53 & 1.66 & 1.55 & 1.01 \\
\hline Deadmoose & 5.88 & 2.32 & 6.81 & 2.11 & 1.29 & 0.98 \\
\hline Waldsea & 5.03 & 3.01 & 11.36 & 2.22 & 1.94 & 1.23 \\
\hline Redberry & 8.79 & 5.81 & 25.54 & 3.42 & 2.35 & 0.47 \\
\hline Mean \pm SD & $\begin{array}{c}5.5 \pm \\
1.8\end{array}$ & $\begin{array}{c}4.1 \pm \\
1.2\end{array}$ & $13 \pm 6$ & $\begin{array}{c}2.3 \pm \\
0.5\end{array}$ & $\begin{array}{c}1.9 \pm \\
0.4\end{array}$ & $0.9 \pm 0.3$ \\
\hline Antelope & 4.53 & 5.65 & 14.08 & 1.95 & 1.28 & 0.91 \\
\hline Success & 3.56 & 3.72 & 9.94 & 1.96 & 1.61 & 0.97 \\
\hline L. Manitou & 2.02 & 2.22 & 3.36 & 1.06 & 1.40 & 0.30 \\
\hline Snakehole & 5.56 & 0.68 & 2.82 & 1.98 & 2.64 & 0.56 \\
\hline Mean \pm SD & $\begin{array}{c}3.9 \pm \\
1.5\end{array}$ & $\begin{array}{c}3.1 \pm \\
2.1\end{array}$ & $\begin{array}{c}7.5 \pm \\
5.4\end{array}$ & $\begin{array}{c}1.7 \pm \\
0.4\end{array}$ & $\begin{array}{c}1.7 \pm \\
0.6\end{array}$ & $0.7 \pm 0.3$ \\
\hline
\end{tabular}

packing. Standard deviation of NND (SDNND) measures evenness of species packing

Analysis of Variance (SPSS version 16.0) determined that the differences in metrics were significant for CR, NR, TA, CD, and NND ( $p<0.05$ for all) between freshwater and mesosaline lakes and freshwater and saline lakes.

Community wide metrics changed predictably with environmental variables (Table 5). CR had a positive correlation to fish complexity, salinity and TKN. NR had a significant negative association with salinity, fish complexity, TKN, DOC, and TP. Total area had a significant positive correlation to fish complexity and significant negative correlations to salinity, TKN, and DOC. Centroid distance had a significant positive correlation with fish complexity, and negative correlations with TKN, salinity, and TP. NND had positive correlations to DOC and salinity and a negative correlation to chlorophyll $a$ concentration. Standard deviation of NND was not significantly correlated to any environmental parameters. Stepwise multiple linear regressions determined that salinity had a negative influence on NR, while fish 
Table 5 Pearson correlation coefficients $(r)$ of the environmental influence on community-wide metrics

\begin{tabular}{|c|c|c|c|c|c|}
\hline \multirow[b]{2}{*}{ Variables } & $\mathrm{CR}$ & NR & TA & $C D$ & NND \\
\hline & \multicolumn{5}{|c|}{$r$} \\
\hline Salinity & -0.57 & -0.76 & -0.78 & -0.62 & 0.60 \\
\hline TKN & -0.52 & -0.70 & -0.72 & -0.64 & 0.52 \\
\hline $\mathrm{NH}_{4}$ & -0.48 & -0.40 & -0.49 & -0.48 & 0.02 \\
\hline $\mathrm{TP}$ & -0.25 & -0.62 & -0.53 & -0.60 & 0.47 \\
\hline Chl a & -0.22 & 0.19 & 0.04 & -0.19 & -0.61 \\
\hline DOC & -0.42 & -0.72 & -0.68 & -0.56 & 0.66 \\
\hline Fish complexity & 0.65 & 0.74 & 0.83 & 0.72 & -0.53 \\
\hline
\end{tabular}

Bold denotes significance. See Table 4 for abbreviations of community metrics.

complexity had significant positive correlations to CR, $\mathrm{TA}$, and CD (Table 6).

\section{Discussion}

This stable isotope study showed that lakes across the Canadian Great Plains are characterized by a very large range in trophic complexity. Trophic diversity, number of trophic levels, and trophic redundancy were highest in productive freshwater lakes with extensive fish communities. In contrast, all of these community metrics were strongly reduced in mesosaline and saline lakes. Variables that were most influential for changes in trophic complexity were salinity, fish complexity, and indicators of productivity (e.g. nutrients, Chl $a$ ). Furthermore, stable isotope analysis revealed that 1 ) lakes that were characterized by very low or no predation pressure from fishes were not colonized by larger invertebrate predators as it is often the case in boreal systems $[30,31], 2)$ fishes could actually represent a lower trophic level than invertebrates as it was the case in Redberry Lake, and 3) energy sources other than phytoplankton that were more depleted in ${ }^{13} \mathrm{C}$ might be important for pelagic communities in some lakes.

\section{Temporal variability}

The $\delta^{13} \mathrm{C}$ values of individual zooplankton groups varied by several \%o within individual lakes, and the degree of

\begin{tabular}{|c|c|c|c|}
\hline Metric & Standardized coefficients & $p$ & $r_{\text {adj. }}^{2}$ \\
\hline$C R$ & 0.6 fish complexity & $<0.01$ & 0.39 \\
\hline NR & -0.8 salinity - 0.6 TDP & $<0.01$ & 0.64 \\
\hline TA & 0.8 fish complexity & $<0.01$ & 0.67 \\
\hline$C D$ & 0.7 fish complexity & $<0.01$ & 0.50 \\
\hline NND & $0.7 \mathrm{DOC}-0.6 \mathrm{Chl} a$ & $<0.01$ & 0.54 \\
\hline
\end{tabular}

See Table 4 for abbreviations of community metrics. Standard deviation of NND was not significantly correlated to any of the environmental variables variability (range) was positively correlated to nutrient concentrations and algal biomass $(\mathrm{Chl} a)$. Elevated values in $\delta^{13} \mathrm{C}$ of primary producers and consumers have previously been observed in other eutrophic systems [32-34], which is associated with an increased demand for $\mathrm{CO}_{2}$ by photosynthetic algae and a subsequent reduction in fractionation factors during photosynthetic uptake [35]. Eutrophic systems are more often characterized by large changes in productivity [36], and the associated seasonal changes in $\mathrm{CO}_{2}$ demand that subsequently impact fractionation factors are likely responsible for the large observed ranges in $\delta^{13} \mathrm{C}$. An alternative scenario is that respired $\mathrm{CO}_{2}$ from bottom waters with low $\delta^{13} \mathrm{C}$ [37] was taken up by phytoplankton and increased the range in $\delta^{13} \mathrm{C}$. But this is unlikely as the study lakes and most other prairie lakes are polymictic, preventing the accumulation of respired $\mathrm{CO}_{2}$ in bottom waters during summer. The positive association of $\delta^{15} \mathrm{~N}$ range with productivity ((Secchi $(-)$, Chl $a(+)$, nutrients $(+))$ is likely due to the increased importance of cyanobacteria in these eutrophic lakes. Dissolved nitrogen sources, e.g., $\mathrm{NH}_{4}{ }^{+}, \mathrm{NO}_{3}{ }^{-}$, and urea, have higher $\delta^{15} \mathrm{~N}$ values of 5 to $8 \%$ in prairie lakes [38]. In contrast, atmospheric $\mathrm{N}_{2}$ has a $\delta^{15} \mathrm{~N}$ value of $0 \%$ $[39,40]$. When dissolved nitrogen sources become limiting, the uptake of atmospheric $\mathrm{N}_{2}$ by cyanobacteria gains in importance, and primary producers will become isotopically more depleted. The temporary dependence on atmospheric nitrogen will result in large changes in $\delta^{15} \mathrm{~N}$ values [40], which will be more pronounced and more frequently in eutrophic systems.

Circular statistics showed that temporal changes in $\delta^{13} \mathrm{C}$ of consumers followed a predictable pattern as values increased from June to August in almost all lakes in both years. In most lakes Chl $a$ was highest in August, hence the trend of elevated $\delta^{13} \mathrm{C}$ during this time provides further evidence that changes in $\delta^{13} \mathrm{C}$ values were largely associated with primary production. Since there were no significant changes in $\delta^{13} \mathrm{C}$ values among years, the effect of increasing productivity over the course of the summer seems to be an annual, seasonal phenomenon in eutrophic prairie lakes. Accordingly, while the range in $\delta^{13} \mathrm{C}$ represents a measure of the differences in productivity among lakes, the seasonal changes in $\delta^{13} \mathrm{C}$ indicate an increased productivity in late summer that is common to all lakes.

In contrast to the relatively constant $\delta^{13} \mathrm{C}$ values between years, there was a small but significant shift in $\delta^{15} \mathrm{~N}$ values from June 2007 to June 2008. The lower $\delta^{15} \mathrm{~N}$ of primary consumers in June 2007 relative to 2008 was probably due to an increased importance of nitrogen from $\mathrm{N}_{2}$-fixing cyanobacteria reaching higher trophic levels during this time. Conversely, dissolved nitrogen sources with higher $\delta^{15} \mathrm{~N}$ could have had larger 
contributions in June 2008. Humboldt Lake always had the highest $\delta^{15} \mathrm{~N}$ values among all lakes (Figure 3). Past research has shown that enriched $\delta^{15} \mathrm{~N}$ values are a good indicator for sewage or manure contamination $[41,42]$. Since such elevated $\delta^{15} \mathrm{~N}$ values have been previously documented for Humboldt Lake $[5,43]$ this contamination seems to be chronic rather that an isolated event.

\section{Food-web dynamics}

The approach of using community-wide metrics has been applied to a number of systems since introduced by Layman et al. [28], including terrestrial [44] and aquatic ecosystems $[14,45]$. Despite criticism that this method is not applicable to all trophic systems [46], it is useful in trophic analysis under finite conditions, such as using trophic baselines or including co-variables, like species richness [47]. Our study applied these metrics as relative measures to evaluate ecological patterns across a large number of lakes that otherwise cannot be compared systematically. We feel that these stable-isotope based, community-wide metrics represent a more objective approach compared to previous studies on prairie or saline lake food-webs that were solely based on empirical evidence for the importance of environmental parameters. Nevertheless, we point out that the strength of our analysis is in the among-lake comparison and not in reporting absolute values of metrics for individual lakes, because due to sample-size limitations (amount) small taxa (e.g., rotifers, bosminids) were excluded from the analyses, and the pelagic fish community might be underrepresented because of the sampling design for fishes.

Most of the community-wide metrics were significantly different between food webs in freshwater $(<2 \mathrm{~g}$ $\left.\mathrm{L}^{-1}\right)$, mesosaline $\left(2-12 \mathrm{~g} \mathrm{~L}^{-1}\right)$, and saline lakes $\left(>12 \mathrm{~g} \mathrm{~L}^{-}\right.$ $\left.{ }^{1}\right)$. $C R$ in saline lakes was probably lower due to strongly decreased species diversity in both pelagic and littoral habitats [8]. Complexity of fish assemblage had a significant positive relationship with the range in carbon stable isotope values (CR). Because fishes did not represent minimum or maximum $\delta^{13} \mathrm{C}$ values in any of the lakes, the elevated CR is likely related to increased food-web complexity when predators are present [48], and a direct effect of fishes on CR could be excluded. In three lakes (Kipabiskau, Humboldt and Redberry), we encountered copepods with lower $\delta^{13} \mathrm{C}$ values relative to all other crustaceans, indicating the presence of an additional energy source. Methane, commonly associated with low $\delta^{13} \mathrm{C}$ values [49] is unlikely to be the cause, as high sulfate concentrations in the study lakes would largely prevent methanogenesis [50]. Potentially, these low carbon stable isotope values may have been associated with sulfur bacteria [51]. Sulfate concentrations in these lakes are very high (Table 1), and strong activities of sulfur bacteria have been reported for such systems [52]. Yet, the actual mechanisms of the energy transfer from bacteria to higher trophic levels will have to be determined in future analyses.

The range in nitrogen stable isotope values (NR) was strongly associated with fish complexity. This is intuitive as lakes with a more complex fish community also encompassed more trophic levels, particularly as the increase in NR between freshwater and mesosaline lakes $(3-4 \%)$ represented approximately one trophic level. In addition to the direct effect of fish presence on diversity, predators are also known to increase food-web complexity [48]. Ultimately, the high NR values in freshwater lakes are indicative of high trophic diversity, suggesting more energy transfer to higher trophic levels [44]. Surprisingly, in mesosaline Redberry Lake, fishes did not represent the highest trophic level as the copepod $D$. nevadensis had higher $\delta^{15} \mathrm{~N}$ that stickleback. As D. nevadensis was also associated with an additional energy source in this lake (see above), it is unclear if the high $\delta^{15} \mathrm{~N}$ values were a true indicator of trophic level or if it was caused by high $\delta^{15} \mathrm{~N}$ values of this additional energy source.

TA (total area) is a combination of CR and NR, as it integrates both metrics. Since TA represents total trophic diversity in food webs, it was not surprising that saline lakes had significantly lower TA values than their freshwater counterparts. CD (centroid distance), which represented average trophic diversity, was higher in freshwater lakes but not significantly different from saline lakes, possibly because the variability that is associated with differences within the littoral and pelagic areas was fairly high. Nevertheless, similar to CR, NR, and TA, regression analyses showed that $\mathrm{CD}$ increased with fish complexity and decreased with salinity, indicating positive and negative correlations to trophic diversity, respectively. The association of environmental parameters with nearest neighbor distance (NND, representing species packing) was opposite compared to the other metrics. NND was positively correlated to salinity and negatively correlated to fish complexity. As salinity increased, niches were occupied by fewer species, creating greater isotopic separation between individual taxa. However, the decrease of NND in freshwater lakes suggests an increase in competition and trophic redundancy [28]. Furthermore, NND was the only metric to be affected by Chl $a(r=-0.61)$, confirming that the trophic redundancy among individual taxa was larger in eutrophic lakes.

Similar to previous community-composition analyses [8], stable isotope based metrics illustrated that salinity and fish complexity were the most significant influences within prairie lake food-webs. Salinity acted as the 
master variable for food-web composition in prairie lakes, having direct and indirect influences on biological (predation) and other chemical factors (e.g.: TKN and DOC) within the study lakes [7]. Changes in predation generated by the presence or absence of piscivorous and planktivorous fish created the second most important parameter regarding species composition within these ecosystems as predation influenced both pelagic and littoral communities. The fish exerted a top-down control of the food webs in both habitats [53], and with increasing salinity, their influence was removed.

Unfortunately, at this point it is not possible to clearly separate the effects of salinity and fish predation. While previous analyses focusing on community compositions in these lakes were able to statistically separate the effects of fish assemblage and salinity [8], this was not the case for regression analyses investigating trophic dynamics based on stable isotope analyses. Ongoing, experimental approaches and the inclusion of more freshwater lakes with reduced fish communities (or no fish at all) in future studies should help resolving this complex issue.

\section{Conclusions}

Several lines of evidence indicated that salinity and complexity of fish assemblages had the most significant effects on biodiversity and food-web structure in lakes across the northern Great Plains. This is of special importance because salinity levels in prairie lakes are known to be sensitive to climatic variability [4], especially in endorheic drainage basins [6]. The IPCC (2007) reports that the Canadian prairies are one of the most at-risk areas to climate change, and small lakes that are a dominant landscape feature across the prairies will be particularly sensitive $[54,55]$. Species composition and biodiversity of pelagic zooplankton are most strongly affected by increasing salinities ([6-8]), and hence these taxa might undergo the most dramatic changes in the future. In contrast, lakes with a high abundance of less sensitive littoral macroinvertebrates $[6,8]$ may become a refuge for fishes that can persist at elevated salinities and adapt to flexible foraging strategies. Furthermore, as freshwater lakes will become rarer, the controlling mechanisms of food-web composition may also switch from predation, which is typical for freshwater lakes, to competition, osmotic stress and perhaps nutrient availability (bottom-up effects) in more saline lakes.

\section{Acknowledgements}

We would like to thank K. Hobson, P. Leavitt and B. Hall for their comments on this manuscript. P. Leavitt also gave logistical support for field research. We would like to thank S. Chow, D. Scott, M. Bogard, K. Scott, R. Hlasny, and N. Henderson for their assistance in field sampling; and S. Chow, D. Scott, and Z. Quiñones-Rivera for their assistance in laboratory analysis. Financial assistance was provided by an NSERC grant to B. Wissel, research grants from Prairie Adaption Research Collaborative (PARC) to B. Wissel and R. Cooper, Saskatchewan Ministry of Environment Fish and Wildlife Development Fund grant to R. Cooper, and Teaching Assistance and Research scholarships from University of Regina and the Faculty of Graduate Studies and Research to R. Cooper.

\section{Authors' contributions}

RNC and BW developed the study design and conducted the field operations. RNC prepared all samples for stable isotope analysis, performed stable- isotope based community-metrics and statistical analyses, and prepared the initial draft of the manuscript as part of a MS thesis. BW conducted all stable isotope analyses and prepared the final draft of the manuscript. All authors read and approved the final manuscript.

\section{Competing interests}

The authors declare that they have no competing interests.

Received: 20 September 2011 Accepted: 16 March 2012 Published: 16 March 2012

\section{References}

1. Last WM, Ginn FM: Saline systems of the great plains of western Canada: an overview of the limnogeology and paleolimnology. Sal Syst 2005, 1:1-38.

2. Pham SV, Leavitt PR, McGowan S, Wissel B, Wassenaar LI: Spatial variability of prairie lake hydrology as revealed using stable isotpes of hydrogen and oxygen. Limnol Oceanogr 2009, 54:101-118.

3. Rawson DS, Moore JE: The saline lakes of Saskatchewan. Can J Res 1944, 22:141-201.

4. van der Kamp G, Keir S, Evans MS: Long-term water level changes in closed-basin lakes of the Canadian prairies. Can Water Resour J 2008, 33:23-38.

5. Pham SV, Leavitt PR, McGowan S, Peres-Neto P: Spatial variability of climate and land-use effects on lakes of the northern Great Plains. Limnol Oceanogr 2008, 53:728-742.

6. Hammer UT: Saline lake ecosystems of the world MA: Kluwer Academic Publishing; 1986.

7. Wissel B, Cooper RN, Leavitt PR, Pham SV: Hierarchical regulation of zooplankton composition in lakes of the northern great plains: an earlywarning model for inter-decadal effects of future climate change. Glob Change Biol 2011, 17:172-185.

8. Cooper RN: Interactive effects of chemical and biological controls of food-web structure in prairie lakes. MSC thesis University of Regina; 2010.

9. Peterson BJ, Fry B: Stable isotopes in ecosystem studies. Ann Rev Ecol Syst 1987, 18:293-320.

10. Post DM: Using stable isotopes to estimate trophic position: models, methods, and assumptions. Ecology 2002, 83:703-718.

11. Cole ML, Kroeger KD, Mcclelland JW, Valiela I: Effects of watershed use on nitrogen concentrations and $\delta^{15}$ nitrogen in groundwater. Biogeochem 2006, 77:199-215.

12. Kao SJ, Liu KK: Stable carbon and nitrogen isotope systematics in an human-disturbed watershed (Lanyang-Hsi) in Taiwan and the estimation of biogenic particulate organic carbon and nitrogen fluxes. Glob Biogeochem Cycl 2000, 14:189-198.

13. Vander Zanden MJ, Rasmussen JB: Comparing trophic position of freshwater fish species using stable nitrogen isotopes and literature dietary data. Can J Fish Aquat Sci 1997, 54:1142-1158.

14. Layman CA, Quattrochi JP, Peyer CM, Allgeier JE: Niche width collapse in a resilient top predator following ecosystem fragmentation. Ecol Lett 2007, 10:937-944.

15. Schmidt SN, Olden JP, Solomon CT, Vander Zanden MJ: Quantitative approaches to the analysis of stable isotope food web data. Ecology 2007, 88:2793-2802.

16. Laird KR, Fritz SC, Maasch K, Cumming BF: Greater drought intensity and frequency before AD 1200 in the Northern Great Plains, USA. Nature 1996, 384:552-554.

17. Wellburn B: The spectral determination of Chlorophyll-A and Chlorophyll$B$, as well as total carotenoids, using various solvents with spectrophotometers of different resolution. J Plant Phys 1994, 144:307-313. 
18. D'Elia CF, Steudler PA, Corwin N: Determination of total nitrogen in aqueous samples using persulfate digestion. Limnol Oceanogr 1977, 22:760-764.

19. Stainton MP, Capel MJ, Armstrong AJ: The chemical analysis of freshwater. Environment Canada Miscellaneous Publication; 21977.

20. Bucke D: The anatomy and histology of the alimentary tract of the carnivorous fish the pike Esox lucius. J Fish Biol 1971, 3:421-431.

21. Weidel B, Carpenter SR, Cole RJ, Hodgson J, Kitchell JJ, Pace M, Solomon C: Carbon sources supporting fish growth in a north temperate lake. Aquat Sci 2008, 70:446-458

22. Scott WB, Crossman EJ: Freshwater fishes of Canada. Bull Fish Res Board Can 1973, 184:1-966

23. Aliberti MA, Allen E, Allard S: An image-based key to the zooplankton of the northwest USA.[http://cfb.unh.edu/cfbkey/html/index.html].

24. Pennak RW: Freshwater invertebrates of North America Toronto: Wiley; 1989.

25. Saether OA: Neartic and palaeartic Chaoborus (Diptera, Chaoboridae). Fish Res Board Can 1970, 174:1-57.

26. Pinnegar JK, Polunin NVC: Differential fractionation of $\delta^{13} \mathrm{C}$ and $\delta^{15} \mathrm{~N}$ among fish tissues: Implications for the study of trophic interactions. Funct Ecol 1999, 1999(13):225-231.

27. Beaudoin CP, Tonn WM, Prepas EE, Wassenaar LI: Individual specialization and trophic adaptability of northern pike (Esox lucius): an isotope and dietary analysis. Oecologia 1999, 120:386-396.

28. Layman CA, Arrington DA, Montana CG, Pos DM: Can stable isotope ratios provide for community-wide measures of trophic structure? Ecology 2007, 88:42-48

29. Cornwell WK, Schwilk DW, Ackerly DP: A trait-based test for habitat filtering: convex hull volume. Ecology 2006, 87:1465-1471.

30. Strecker AL, Arnott SE: Invasive predator, Bythotrephes, has varied effects on ecosystem function in freshwater lakes. Ecosystems 2008, 11:490-503.

31. Wissel B, Yan ND, Ramcharan CW: Predation and refugia: implications for Chaoborus abundance and species composition. Freshw Biol 2003, 48:1421-1431.

32. Lehmann MF, Bernasconi SM, McKenzie JA: Seasonal variation of the $\delta 13 C$ and $\delta 15 \mathrm{~N}$ of particulate and dissolved carbon and nitrogen in Lake Lugano: constraints on biogeochemical cycling in a eutrophic lake. Limnol Oceanogr; 2004:49:415-429.

33. O'Leary MH: Carbon isotopes in photosynthesis. Biosciences 1988 , 38:328-336.

34. Wissel B, Gace A, Fry B: Tracing river influences on phytoplankton dynamics in two Louisiana estuaries. Ecology 2005, 86:2751-2762.

35. France RL: Differentiation between littoral and pelagic food webs in lakes using stable carbon isotopes. Limnol Oceanogr 1995, 40:1310-1313.

36. Winder $M$, Cloern JE: The annual cylces of phytoplankton biomass. Phil Trans $R$ Soc 2010, 365:3215-3226

37. del Giogio PA, France RL: Ecosystem-specific patterns in the relationship between zooplankton and POM or microplankton $\delta^{13} \mathrm{C}$. Limnol Oceanogr 1996, 41:359-365.

38. Leavitt PR, Brock CS, Ebel C, Patoine A: Landscape-scale effects of urban nitrogen on a chain of freshwater lakes in central North America. Limnol Oceanogr 2006, 51:2262-2277

39. Gu B: Variations and controls of nitrogen stable isotopes in particulate organic matter of lakes. Oecologia 2009, 160:421-431.

40. Patoine $A$, Graham MD, Leavitt PR: Spatial variation of nitrogen fixation in lakes of the northern Great Plains. Limnol Oceanogr 2006, 2006(51):1665-1677.

41. Daskalou V, Vreča P, Muri G, Stalikas C: Recent environmental changes in the shallow Lake Pamvotis (NW Greece): evidence from sedimentary organic matter, hydrocarbons, and stable isotopes. Arch Environ Contam Toxicol 2009, 57:21-31.

42. Sweeney RE, Kalil EK, Kaplan IR: Characterization of domestic and industrial sewage in Southern California coastal sediments using nitrogen, carbon, sulphur and uranium tracers. Mar Env Res 1980, 3:225-243.

43. Rusak JA, Leavitt PR, McGowan S, Chen C, Olson OG, Wunsum S, Cumming BF: Millennial-scale relationships of diatom species richness and production in two prairie lakes. Limnol Oceanogr 2004, 49:1290-1299.

44. Okuzaki Y, Tayasu I, Okuda N, Sota T: Vertical heterogeneity of a forest floor invertebrate food web as indicated by stable-isotope analysis. Ecol Res 2009, 24:1351-1359.
45. Quevedo M, Svanbäck R, Eklöv P: Intrapopulation niche partitioning in a generalist predator limits food web connectivity. Ecology 2009, 90:2263-2274.

46. Hoeinghaus DJ, Zeug SC: Can stable isotope ratios provide for community-wide measures of trophic structure? Comment. Ecology 2008, 89:2253-2257, Intergovernmental Panel on Climate Change: Fourth Assessment Report of the IPCC. IPCC, Paris; 2007

47. Layman CA, Pos DM: Can stable isotope ratios provide for communitywide measures of trophic structure? Reply. Ecology 2008, 89:2258-2259.

48. Finke DL, Denno RF: Predator diversity dampens trophic cascades. Nature 2004, 429:407-410

49. Barker JF, Fritz P: Carbon isotope fractionation during microbial methane oxidation. Nature 1981, 293:289-291.

50. Winfrey MR, Zeikus JG: Effects of sulfate on carbon and electron flow during microbial methanogenesis in feshwater sediments. Appl Environm Microbiol 1977, 33:275-281.

51. Zyakun AM, Lunina ON, Prusakova TS, Pimenov NV, Ivanov MV: Fractionation of stable carbon isotopes by photoautotrophically growing anoxygenic purple and green sulfur bacteria. Microbiol 2009, 78:757-768.

52. Van Gemerden H, Das J: Ecology of photosynthetic sulfur bacteria. Adv Photosynth Respiration 2004, 2:49-85.

53. Vander Zanden MJ, Essington TE, Vadeboncoeur $Y$ : Is pelagic top-down control in lakes augmented by benthic energy pathways? Can J Fish Aquat Sci 2005, 62:1422-1431

54. Millett B, Johnson WC, Guntenspergen G: Climate trends of the North American prairie pothole region 1906-2000. Climat Chang 2009, 93:243-267.

55. Zhang B, Schwartz FW, Liu G: Systematics in the size structure of prairie pothole lakes through drought and deluge. Water Resour Res 2009, 45, doi:10.1029/2008WR006878.

doi:10.1186/2046-9063-8-6

Cite this article as: Cooper and Wissel: Loss of trophic complexity in saline prairie lakes as indicated by stable-isotope based communitymetrics. Aquatic Biosystems 2012 8:6.

\section{Submit your next manuscript to BioMed Central and take full advantage of:}

- Convenient online submission

- Thorough peer review

- No space constraints or color figure charges

- Immediate publication on acceptance

- Inclusion in PubMed, CAS, Scopus and Google Scholar

- Research which is freely available for redistribution

Submit your manuscript at www.biomedcentral.com/submit
C) Biomed Central 